\title{
A PRELIMINARY REPORT ON THE ICHTHYOFAUNA OF KALIVELI FLOODPLAIN AND UPPUKALLI CREEK, PONDICHERRY, INDIA, WITH SOME NOTES ON HABITAT, DISTRIBUTION, STATUS AND THREATS
}

\author{
Mario Eric Ramanujam \\ Principal Investigator (Fauna), ECTDEF Project, Pitchandikulam Bioresource Centre, Auroville, Pondicherry 605101, India \\ Email: tdef@auroville.org.in
}

\begin{abstract}
There are, at present, at least 42 species of fish inhabiting Kaliveli floodplain and Uppukalli creek. Six species are confined to the floodplain, 19 are estuarine and 17 occur in both floodplain and creek. The IUCN Red List Category / Conservation status of 21 species could be determined: 1 Endangered, 5 Vulnerable, 14 Near threatened, and 1 Least concern. The only exotic was Oreochromis mossambica which is an Alien Invasive species. High concentrations of Chlorides around prawn farms exist, and this could have adverse effects on aquatic biodiversity.
\end{abstract}

\section{KEYWORDS}

Coromandel coast, estuary, ichthyofauna, India, Kaliveli floodplains, Pondicherry, status, Uppukalli creek, water quality, wetland

Kaliveli has been described as one of the two most important wetlands along the Coromandel coast of southern India - the other is Pulicat (Perennou, 1987; Perennou \& Santharam, 1990). Though the avifauna of Kaliveli has been well documented (Balachandran, 1994; Perennou, 1987, 1989, 1990; Perennou \& Santharam, 1990; Pieter, 1987), only a single note on ichthyofauna based on casual observations is available (Sharma, 1997); this listed just 11 species.

Presented here is a list of fish and water quality analysis of Kaliveli floodplain and Uppukalli creek that provides the basic qualitative data regarding fish distribution, status and perceived threats.

\section{Study AreA}

Kaliveli is a 13,200 ha wetland (the southernmost point lies ca. $20 \mathrm{~km}$ north of Pondicherry city) that extends for ca. $30 \mathrm{~km}$ parallel to the coast. It can be divided into three distinct zones as one moves northward:

1) Kaliveli floodplain $\left(12^{0} 5^{\prime}-12^{0} 3^{\prime}-12^{0} 9^{\prime} \mathrm{N} \& 7^{0} 47^{\prime}-79^{0} 51^{\prime}-79^{0} 53^{\prime} \mathrm{E}\right)$ : Although called a lake or tank, it is by definition a floodplain (Keddy, 2000; Lowe-Mc Connell, 1987). This petal-shaped waterbody, covering an area of 7,040ha. is completely dry during the summer months. It begins to fill up with the advent of the southwest monsoons and reaches its maximum extent by the end of the northeast monsoons. Its catchment covers an area of $740 \mathrm{~km}^{2}$ and includes the Auroville plateau to the south, Marakkanam to the north and extends well beyond Tindivanam to the northwest. The copious run-off water from this entire area ultimately reaches the floodplain via the many tanks and streambeds (Fig. 1). channel that connects the floodplain to the estuary. Owing to its estuarine links, the character of this area is distinct from that of the floodplain. There is constant inflow of water from the estuary throughout the year and the water level varies with the tides and sea level.

3) Yedayanthittu estuary $\left(12^{0} 12^{\prime}-12^{0} 15^{\prime} \mathrm{N} \& 79^{0} 56^{\prime}-80^{\circ} 0^{\prime} \mathrm{E}\right)$ : Extending from a little north of Marakkanam road bridge to the point when it drains into the Bay of Bengal at Alamparai. It is an area of intertidal mudflats and salt pans. It was once linked to Pulicat lake $42 \mathrm{~km}$ north of Chennai via the Buckingham Canal (Scott, 1989). This area was not assessed during this study.

The common aquatic vegetation is Aponogeton natans, Eichhornia crassipes, Hydrilla verticillata, Limnophyton obtusifolium, Monochoria vaginalis, Vallisneria spiralis, Aristida adscensionis, Chloris barbata, C. montana, Polygala arvensis, Lindernia crastacea, Scoparia dulcis and Waltheria indica. Acacia nilotica, Alternanthera sessilis, Bacopa monnieri, Coldenia procumbens, Cyperas distans, Eclipta prostrata, Heliotropium indicum, Hygrophila angustifolia, Ludwigia perennis, Phyla nodiflora, Polygonum barbatum and Typha angustata are found along the boundaries.

This region has a climatic dissymmetric regime. January to June is the statistically dry season. From July to September some rain is received due to the southwest monsoons, but the characteristic of the east coast is the violence of precipitation during the northeast monsoons from depressions formed in the Bay of Bengal. The average rainfall per year is ca. $1,300 \mathrm{~mm}$, the bulk falling during the northeast monsoons in October and November. (Blasco \& Legris, 1972; Meher-Homji, 1975).

The entire area has long been subject to anthropogenic influences. Villages surround the area, croplands border the entire floodplain and encroachments are common (as soon as the water recedes the lake bed is planted with rice and irrigated with ground water). Fishing and poaching are activities directly linked to the fauna of the wetland. The entire area north of Marakkanam Road Bridge is an expanse of salt pans, which until recently was the only sizable industry in the area. The new and rapidly expanding industry is aquaculture - the entire area from Marakkanam Road Bridge, southwards, through Vandipalayam, to Settikuppam is an increasingly vast spread of prawn farms. 


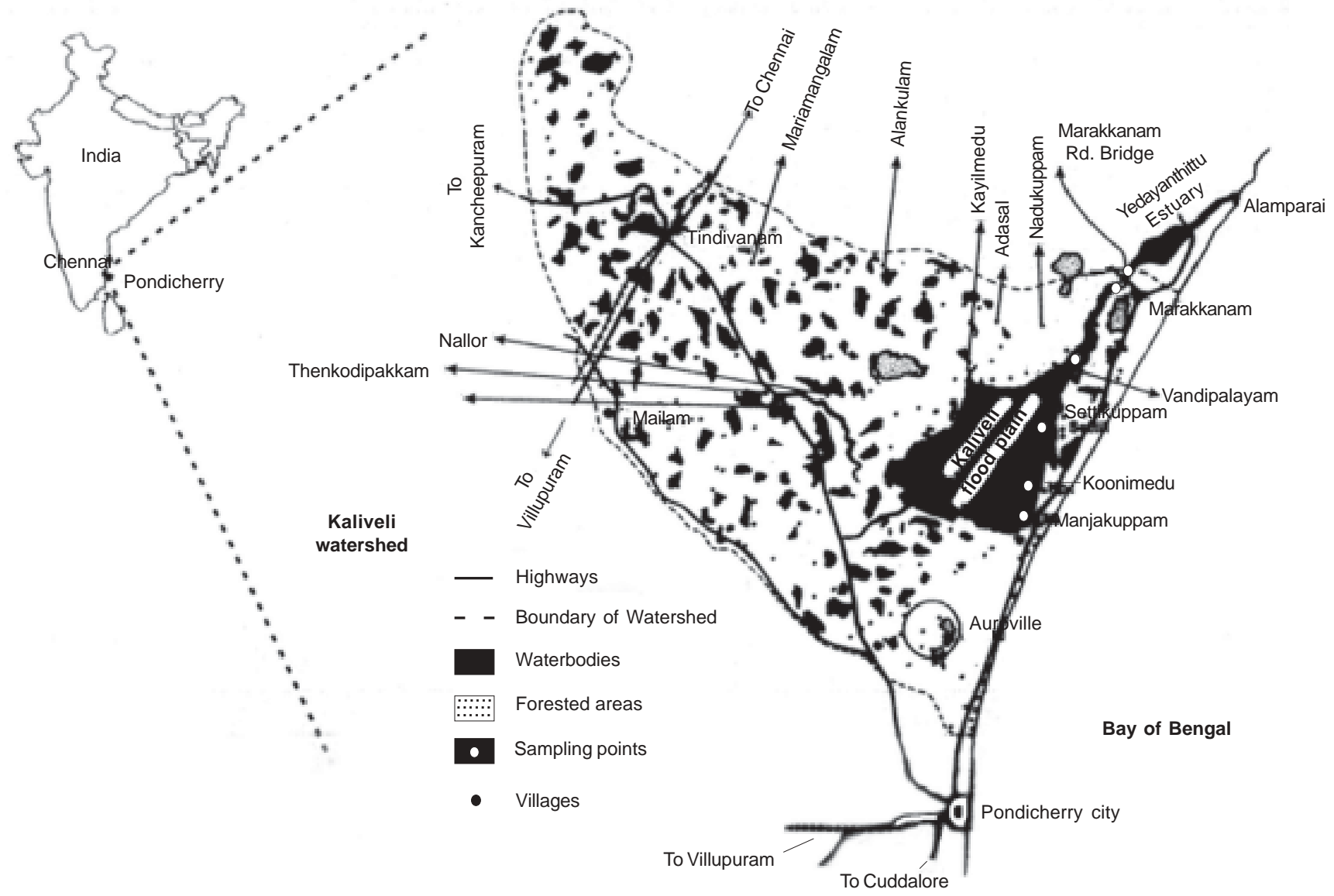

Figure 1. Map of Kaliveli floodplains in Pondicherry

\section{MethoDS}

The study lasted from 21.7.2003 to 30.4.2004 - ie., from the time the first rains set in during the Southwest Monsoons to the time the floodplain dried up.

Specimens were collected with the help of local fishermen who used hand operated dragnets, casting nets, and the hook and line. In addition, small stranded fish (that commercialists ignore) were collected by the research team using dip nets. 5 collection points, regularly fished, were identified: three points along the eastern shore of the floodplain (Manjakuppam, Koonimedu and Settikuppam) and two points along the creek (Vandipalayam and either side of Marakkanam Road Bridge).

Identification of freshwater fishes was based on established literature (Daniels, 2002; Jayaram, 1999; Talwar \& Jhingran, 1991). Nomenclature and classification was after Daniels (2002). Marine / estuarine species were identified by a well respected expert who wishes to remain anonymous.

Water samples were collected at all the above mentioned points and analysed by the Environmental Monitoring Service at Auroville as per the method prescribed by the Indian Standard Institution (Anon., 1964).
IUCN Conservation status / category of species was established by the Biodiversity Conservation Prioritisation Project (BCPP) and Conservation Assessment and Management Plan Workshops (CAMP) (Molur \& Walker, 1998, Rao et al., 1998).

\section{Results}

42 species of fish representing 25 families and nine orders were collected. Six species were confined to the floodplain, 19 were estuarine and 17 occurred in both floodplain and creek. Both anadromous (e.g., Hilsa ilisha and Mugil cephalus) and catadromous (Anguilla bengalensis) species were present. Two species listed by Sharma (1997), viz., Shark Catfish Wallago attu and Giant Snakehead Channa (= Ophiocephalus) marulius were not found.

Cultured species - Catla Catla catla, Rohu Labeo rohita, Mrigal Cirrhinus mrigala and Carps Cyprinus spp. - introduced into Alankuppam, Kayalmedu, Thenkodipakkam, Mariamangalam, Metutheru, Nallaoor and Idaicherry tanks within the watershed, were not found to have reached the floodplain.

The only exotic was Oreochromis (= Tilapia) mossambica . This species' predatory nature is said to eliminate all native species (Daniels, 2002). In addition, its prolific breeding and consequent over-population, resulting in severe competition 
Table 1. Species diversity, status and occurrence of fish at Kaliveli floodplain and Uppukalli creek

\begin{tabular}{|c|c|c|c|c|c|c|c|c|}
\hline Scientific Name & English Name & $\begin{array}{l}\text { Local Name } \\
\text { (Pho. Tamil) }\end{array}$ & $\begin{array}{l}\text { Status } \\
\text { in India }\end{array}$ & Man & $\begin{array}{l}\text { Occur } \\
\text { Koo }\end{array}$ & $\begin{array}{l}\text { rence } \\
\text { Set }\end{array}$ & Van & Mar \\
\hline \multicolumn{9}{|l|}{ Anguilliformes } \\
\hline 1. Anguilla bengalensis & Indian Long-finned Eel & Vilangu & EN & A & $\mathrm{P}$ & $\mathrm{P}$ & $\mathrm{P}$ & $\mathrm{P}$ \\
\hline \multicolumn{9}{|l|}{$\begin{array}{l}\text { Clupeiformes } \\
\text { Clupeidae }\end{array}$} \\
\hline 2. Hilsa ilisha & Hilsa, Indian Shad & Ullam & VU & $P$ & $P$ & $\mathrm{P}$ & $P$ & $\mathrm{P}$ \\
\hline $3 \quad$ Nematalosa nasus & Bloch's Gizzard Shad & Ponneli, Ponn kendai & LR-nt & $\mathrm{P}$ & $\mathrm{P}$ & $P$ & $\mathrm{P}$ & $\mathrm{P}$ \\
\hline $4 \quad$ Nematalosa galatheae & Gizzard Shad & Ponneli, Ponn kendai & $\mathrm{x}$ & $P$ & $\mathrm{P}$ & $\mathrm{P}$ & $\mathrm{P}$ & $\mathrm{P}$ \\
\hline $5 \quad$ Clupeasp. & Sardine & Nethili & $x$ & A & A & $\mathrm{P}$ & $\mathrm{P}$ & $\mathrm{P}$ \\
\hline $6 \quad$ Thryssa sp. & Anchovy & Poriva & $x$ & $A$ & A & A & $A$ & $\mathrm{P}$ \\
\hline $7 \quad$ Coilia sp. & Anchovy & Poriva & $x$ & A & A & A & $\mathrm{P}$ & $\mathrm{P}$ \\
\hline \multicolumn{9}{|l|}{$\begin{array}{l}\text { Gonorhynchiformes } \\
\text { Chanidae }\end{array}$} \\
\hline 8. Chanos chanos & Milkfish & Kulla kendai & LR-nt & $\mathrm{P}$ & $\mathrm{P}$ & $\mathrm{P}$ & $\mathrm{P}$ & $\mathrm{P}$ \\
\hline \multicolumn{9}{|l|}{ Cypriniformes } \\
\hline 9. Puntius sophore & Spotfin Barb & Kosuru Meen & LR-nt & $\mathrm{P}$ & $\mathrm{P}$ & $\mathrm{P}$ & A & A \\
\hline \multicolumn{9}{|l|}{ Siluriformes } \\
\hline 10. Aorichthys seenghala & Giant River Catfish & Periya keluthi & $x$ & A & $\mathrm{P}$ & A & A & A \\
\hline $11 \quad$ Mystus gulio & Long-whiskered Catfish & Keluthi & $x$ & $P$ & $\mathrm{P}$ & $\mathrm{P}$ & $\mathrm{P}$ & $\mathrm{P}$ \\
\hline 12 Mystus vittatus & Striped Dwarf Catfish & Keluthi & VU & $\mathrm{P}$ & $\mathrm{P}$ & $P$ & $\mathrm{P}$ & A \\
\hline 13 Tachysurus subrostratus & Marine Catfish & Visha keluthi & $x$ & A & A & A & A & $\mathrm{P}$ \\
\hline 14 Tachysurus thassinus & Marine Catfish & Visha keluthi & $x$ & A & A & $A$ & $A$ & $P$ \\
\hline 15 Tachysurus arius & Marine Catfish & Visha keluthi & $x$ & A & A & A & A & $\mathrm{P}$ \\
\hline 16 Clarius batrachus & Magur / Black Walking & $\begin{array}{l}\text { Masarai keluthi } \\
\text { Catfish }\end{array}$ & VU & A & $\mathrm{P}$ & A & A & A \\
\hline \multicolumn{9}{|l|}{ Mulgiformes } \\
\hline 17. Mugil cephalus & Common mullet & Madavai, Periya Madavai & LR-nt & A & $\mathrm{P}$ & $\mathrm{P}$ & $\mathrm{P}$ & $\mathrm{P}$ \\
\hline $18 \quad$ Liza dussumeri & Mullet & Madavai & LR-nt & A & A & A & $\mathrm{P}$ & $\mathrm{P}$ \\
\hline 19 Liza macrolepis & Mullet & Madavai & LR-nt & A & A & $A$ & $\mathrm{P}$ & $\mathrm{P}$ \\
\hline $20 \quad$ Liza parsia & Mullet & Madavai, & LR-nt & A & A & A & $\mathrm{P}$ & $\mathrm{P}$ \\
\hline \multicolumn{9}{|l|}{$\begin{array}{l}\text { Beloniformes } \\
\text { Hemiramphidae }\end{array}$} \\
\hline 21. Hyporhamphus limbatus & Indian/Congaturi Halfbeak & Otha-mookku kola & $x$ & $\mathrm{P}$ & $\mathrm{P}$ & $\mathrm{P}$ & $\mathrm{P}$ & A \\
\hline \multicolumn{9}{|l|}{ Belonidae } \\
\hline 22. Strongylura strongylura & Fullbeak Gar & Retta- mookku kola, Kola & $x$ & A & A & $\mathrm{P}$ & $\mathrm{P}$ & $\mathrm{P}$ \\
\hline \multicolumn{9}{|l|}{ Adrianithydae } \\
\hline \multicolumn{9}{|l|}{$\begin{array}{l}\text { Perciformes } \\
\text { Chandidae }\end{array}$} \\
\hline 24. Ambassis commersoni & Glassy Perchlet & Selathaan & LR-nt & $\mathrm{P}$ & $\mathrm{P}$ & $\mathrm{P}$ & $\mathrm{P}$ & $\mathrm{P}$ \\
\hline \multicolumn{9}{|l|}{ Sillaginidae } \\
\hline 25. Sillago sihama & Silver Sillago & Kezhangan & LR-nt & A & A & A & A & $\mathrm{P}$ \\
\hline \multicolumn{9}{|l|}{ Carangidae } \\
\hline 26. Alepes kalla & Horse Mackerel & Paarai & $x$ & A & A & $A$ & $A$ & $\mathrm{P}$ \\
\hline 27 Leiognathus splendens & - & Kaarai & VU & A & A & A & $\mathrm{P}$ & $\mathrm{P}$ \\
\hline \multicolumn{8}{|l|}{ Gerridae } & $\mathrm{P}$ \\
\hline $\begin{array}{l}\text { Theraponidae } \\
\text { 29. Therapon jarbua } \\
30 \quad \text { Therapon theraps }\end{array}$ & $\begin{array}{l}\text { Target Perch } \\
\text { Target Perch }\end{array}$ & $\begin{array}{l}\text { Keesaan } \\
\text { Manja keesaan }\end{array}$ & $\begin{array}{l}\text { LR-nt } \\
x\end{array}$ & $\begin{array}{l}A \\
A\end{array}$ & $\begin{array}{l}A \\
A\end{array}$ & $\begin{array}{l}A \\
A\end{array}$ & $\begin{array}{l}\mathrm{P} \\
\mathrm{A}\end{array}$ & $\begin{array}{l}\mathrm{P} \\
\mathrm{P}\end{array}$ \\
\hline \multicolumn{8}{|l|}{ Lutjanidae } & $\mathrm{P}$ \\
\hline \multicolumn{8}{|l|}{ Scatophagidae } & $\mathrm{P}$ \\
\hline \multicolumn{4}{|l|}{ Siganidae } & A & A & A & $\mathrm{P}$ & $\mathrm{P}$ \\
\hline \multicolumn{8}{|l|}{ Cichlidae } & $\mathrm{P}$ \\
\hline
\end{tabular}




\begin{tabular}{|c|c|c|c|c|c|c|c|c|}
\hline Scientific Name & English Name & $\begin{array}{l}\text { Local Name } \\
\text { (Pho. Tamil) }\end{array}$ & $\begin{array}{l}\text { Status } \\
\text { in India }\end{array}$ & Man & $\begin{array}{l}\text { Occu } \\
\text { Koo }\end{array}$ & $\begin{array}{l}\text { rence } \\
\text { Set }\end{array}$ & Van & Mar \\
\hline 35 Oreochromis mossambica & Egyptian Mouth Breeder & Zilebi kendai / Tilapia & Invasive** & $\mathrm{P}$ & $\mathrm{P}$ & $P$ & $P$ & $P$ \\
\hline $\begin{array}{l}\text { Gobiidae } \\
\text { 36. Glossogobius giurus }\end{array}$ & Tank Goby & Uluvai & LR-nt & $P$ & $\mathrm{P}$ & $P$ & A & A \\
\hline $\begin{array}{l}\text { Anabantidae } \\
\text { 37. Anabas testudineus } \\
\text { Channidae }\end{array}$ & Climbing Perch & Panangottai meen & VU & $\mathrm{P}$ & $\mathrm{P}$ & $\mathrm{P}$ & $P$ & $P$ \\
\hline $\begin{array}{l}\text { 38. Channa punctatus } \\
39 \text { Channa striatus }\end{array}$ & $\begin{array}{l}\text { Spotted Snakehead } \\
\text { Striped/Banded Snakehead Veral }\end{array}$ & $\begin{array}{l}\text { Kuravai } \\
\text { LR-Ic }\end{array}$ & $\begin{array}{l}\text { LR-nt } \\
\text { A }\end{array}$ & $\begin{array}{l}\mathrm{P} \\
\mathrm{P}\end{array}$ & $\begin{array}{l}\mathrm{P} \\
\mathrm{P}\end{array}$ & $\mathrm{P}$ & $\mathrm{P}$ & A \\
\hline $\begin{array}{l}\text { Pleuronectiformes } \\
\text { Pleuronectidae } \\
\text { 40. Pseudorhombus arsius }\end{array}$ & Tongue Sole / Flounder & Naakku meen & $x$ & $A$ & A & A & A & $\mathrm{P}$ \\
\hline $\begin{array}{l}\text { Tetradontiformes } \\
\text { Sclerodermi } \\
\text { 41. Triacanthus brevirostris }\end{array}$ & Tripod Fish / File Fish & Mulluruvi & $x$ & A & A & A & $P$ & $P$ \\
\hline $\begin{array}{l}\text { Gymnodontes } \\
\text { 42. Tetrodon fluviatilis }\end{array}$ & Puffer Fish / Globe Fish & Pandu meen & $x$ & A & A & A & A & $P$ \\
\hline
\end{tabular}

* IUCN Red List Categories: EN - Endangered (1); VU - Vulnerable (5); LR-nt - Lower Risk, near threatened (14); LR-Ic - Lower Risk, least concern (1);

$x$ - Not evaluated, hence status unknown (20); ${ }^{* *}$ IUCN Status: Anon (2000); ${ }^{* *}$ Occurrence: P - Present; A - Absent

Man - Manjakuppam; Koo - Koonimedu; Set - Settikuppam; Van - Vandipalayam; Mar - Marakkanam Road bridge

Table 2. Water quality at the 5 study points

\begin{tabular}{|c|c|c|c|c|c|c|c|c|c|c|c|c|}
\hline S. No & Collection point & $\begin{array}{l}\text { Month } \\
\text { \& Year }\end{array}$ & $\mathrm{pH}$ & E.C & $\begin{array}{l}\mathrm{CO}_{3} \\
\mathrm{meq} / 1\end{array}$ & $\begin{array}{l}\mathrm{HCO}_{3} \\
\mathrm{meq} / 1\end{array}$ & $\begin{array}{l}\mathrm{Ca} \\
\mathrm{meq} / 1\end{array}$ & $\begin{array}{l}\mathrm{Mg} \\
\mathrm{meq} / 1\end{array}$ & $\begin{array}{l}\mathrm{Cl} \\
\mathrm{meq} / 1\end{array}$ & $\begin{array}{l}\mathrm{Na} \\
\mathrm{meq} / 1\end{array}$ & $\begin{array}{l}\mathrm{K} \\
\mathrm{meq} / 1\end{array}$ & SAR \\
\hline 1. & Manjakuppam & Nov. 2003 & 6.9 & 5.3 & 1.2 & 37.9 & 3.0 & 12.2 & - & 37.1 & 0.5 & 13.5 \\
\hline 2. & Koonimedu & Nov. 2003 & 8.7 & 1.9 & 1.2 & 4.0 & 3.0 & 4.0 & 13.5 & 11.0 & 0.4 & 5.9 \\
\hline 3. & Koonimedu & Feb. 2004 & 7.4 & 4.7 & - & 1.4 & 1.3 & 1.8 & 0.9 & 1.2 & 0.2 & 0.7 \\
\hline 4. & Settikuppam & Nov. 2003 & 8.9 & 5.5 & 0.4 & 0.3 & 2.6 & 9.6 & 41.9 & 42.2 & 0.5 & 17.1 \\
\hline 5. & Settikuppam & Dec. 2003 & 7.2 & 1.3 & - & 6.2 & 4.0 & 2.0 & 6.7 & 4.1 & 2.8 & 2.3 \\
\hline 6. & Settikuppam & Feb. 2004 & 7.4 & 10.9 & - & 18.0 & 20.0 & 30.0 & 132.0 & 104.0 & 3.1 & 14.7 \\
\hline 7. & Vandipalayam & Nov. 2003 & 9.0 & 2.1 & 1.2 & 3.4 & 2.8 & 4.2 & 16.0 & 13.4 & 0.4 & 7.2 \\
\hline 9. & $\begin{array}{l}\text { Marakkanam } \\
\text { Rd. Bridge }\end{array}$ & Mar. 2004 & 7.9 & 62.2 & - & 23.0 & 44.0 & 51.0 & 53.0 & 391.0 & 6.1 & 40.0 \\
\hline
\end{tabular}

with other species and threat to aquatic vegetation (Saxena, 1988), fills the criteria for it being classed as an Alien Invasive species (Anon., 2000).

Of the remaining 41 species collected, the conservation status of only 21 could be determined based on Molur and Walker (1998) and Rao et al. (1998). Threatened species recorded included the Indian Long-finned Eel Anguilla bengalensis (Endangered), Hilsa ilisha, Mystus vittatus, Clarius batrachus, Leiognathus splendens and Anabas testudineus (all Vulnerable). Fishes of Lower Risk categories included 14 near threatened species, and one least concern species (Channa striatus).

In many cases, names used by local fishermen and villagers differed markedly from those used by people in other regions of Tamil Nadu (Table 1).

The striking feature of water quality during the months of February and March 2004 was the presence of very high concentrations of chlorides in the area from Marakkanam road bridge to Settikuppam. This is the area of prawn farms and aquaculturists are known to dump vast quantities of bleaching powder $\left(\mathrm{CaOCl}_{2}\right)$ into the waterbody in an effort to ward off
White-spot Disease which affects cultured prawns. As a result, it is not uncommon to see scores of dead or dying fish littering the banks (Table 2). Water samples analysed for pesticides at the creek around Vandipalayam (Organochlorine: Aldrin \& Dieldrin, Alpha - BHC, Beta - BHC, Gamma - BHC, Endosulfan I \& II, Endosulfan Sulfate, Endrin \& Endrin Aldehyde, Heptachlor \& Heptachlor Epoxide and DDT; Organophosphorous: Dichlorvos, Chlorpyrifos, Parathion Methyl, Malathion and Ethion] showed only the organochloride Beta - BHC to be above the detectable limit $-0.02 \mu \mathrm{g} / \mathrm{l}$ (Correa, pers. comm.).

\section{Discussion}

Extensive flooding leading to temporary lotic conditions during the highwater season is a feature of the Kaliveli catchment. The principal freshwater fish stocks live in the many perennial water bodies within the catchment - Nadukuppam, Adasal, Munnoor, Thenkodipakkam and Kondamoor to mention but a few. Being surprisingly very mobile, many make long lateral journeys along with the floodwaters and reach the floodplain. Here they spawn and an explosive increase in fish stocks takes place. The peak water level and fish biomass is reached at the end of the monsoons and from then on begins to slowly diminish. Towards the end, strandings and heavy predation 
(by both natural predators like waterbirds, and by man) are common. The entire cycle is repeated year after year.

Contrary to popular notion, in tropical lentic environments, there are no clear cut transitions from fresh to brackish water. As with most floodplains in the Oriental Region, Kaliveli has an extensive estuarine reach and immense outpourings of freshwater dilute the sea during the monsoon rains. After the rains abate, saltwater runs up long distances (especially during high tide) and also tends to move up beneath freshwater. All this allows estuarine species to move upriver more easily, and, vice versa, riverine species to reach the estuary. This also is said to facilitate the movement of migratory species.

High concentrations of chlorides around prawn farms will affect fish movements and stocks. The full extent of damage is not yet fully known. Only a detailed analysis and mature interpretation of data can satisfactorily answer empirical demands.

\section{REFERENCES}

Anon. (1964). Methods of sampling and test (physical and chemical) for water and soil. Indian Standards Institution, New Delhi.

Anon. (2000). Species Survival Commission (SSC). Alien invasive species - a global threat to biodiversity. IUCN Guidelines for the prevention of biodiversity loss caused by alien invasive species. Prepared by the SSC Invasive Species Specialist Group. Approved by the $51^{\text {st }}$ meeting of the IUCN Council, Gland, Switzerland, 22pp.

Balachandran, S. (1994). Some interesting bird records from Kaliveli lake near Pondicherry. Journal of the Bombay Natural History Society 91: 317-318. Blasco, F. and P. Legris (1972). Dry evergreen forest of Point Calimere and Marakkanam. Journal of the Bombay Natural History Society 70: 279-286.

Correa, Margarita (Pers. comm.). Water Quality Examination Report Pesticide analysis. Environmental Monitoring Service, Auroville.

Daniels, R.J.R. (2002). Freshwater Fishes of Peninsular India. Universities Press (India) Private Limited, Hyderabad, 288pp.
Jayaram, K.C. (1999). The Freshwater Fishes of the Indian Region. Narendra Publishing House, New Delhi, 551pp.

Keddy, P.A. (2000). Wetland Ecology - Principles and Conservation. Cambridge University Press, 614pp.

Lowe-Mc Connell, R.H. (1987). Ecological Studies in Tropical Fish Communities. Cambridge University Press, 382pp.

Meher-Homji, V.M. (1975). The natural history of Pondicherry and its environs. Revue Historique de Pondicherry 12: 45-54.

Molur, S. and S. Walker (Eds.) (1998). Report of the workshop "Conservation Assessment and Management Plan for Freshwater Fishes of India". Zoo Outreach Organisation, CBSG India, Coimbatore, India, $156 \mathrm{pp}$

Perennou, C. (1987). Two important wetlands near Pondicherry. Blackbuck 3: $1-9$.

Perennou, C. (1989). Southern wintering range of some waterbirds. Journal of the Bombay Natural History Society 86: 247-248.

Perennou, C. (1990). Peuplements d'oiseaux aquatiques en milieu anthropise: un exemple. Les plaines de la cote de Coromandel (Inde du Sud - Est). Diplome de Doctorat, 269pp (Unpublished).

Perennou, C. and V. Santharam (1990). An anthropological survey of some wetlands in South-east India. Journal of the Bombay Natural History Society 87: 354-363.

Pieter (1987). Kaliveli Tank and Yedayanthittu Estuary - a little known wetland habitat in Tamil Nadu. Journal of the Bombay Natural History Society 84: 210214.

Rao, T.A., Molur, S and S. Walker (Eds.) (1998). Report of the workshop "Conservation Assessment and Management Plan for Mangroves of India" (BCPP Endangered Species Project). Zoo Outreach Organisation, CBSG India, Coimbatore, India, 106pp

Saxena, B.S. (1988). Culture of Tilapia in India - a policy issue. Proceedings of the First Indian Fisheries Forum. Asian Fisheries Society, Indian Branch, Mangalore, 39-40pp.

Scott, D.A. (1989). A directory of Asian Wetlands. IUCN, Gland \& Cambridge, 480-483pp.

Sharma, C.B.S.R. (1997). Ecography of small waterbodies. Madras Institute of Development Studies and Ministry of Environment and Forests, 132pp.

Talwar, P.K. and A.G. Jhingran (1991). Inland Fishes of India and Adjacent Countries. Vol. 1\&2. Oxford \& IBH Publishing Co. Pvt. Ltd., 1158pp.

\section{Volunteers needed}

The Chiroptera Conservation and Information Network of South Asia (CCINSA) along with Dr. Shahroukh Mistry, USA, have embarked on a project that involves identification and monitoring of fruit bat (Pteropus giganteus) colonies/roosts all over South Asia. The project will be an ongoing one with regular monitoring of colonies to understand the dynamics, population trends and various other aspects of the region's largest bats.

If you or any one of your colleagues or friends are interested in joining this exciting project, please write with your name, address, occupation, interest in this subject, and the geographical area you would like to participate in monitoring fruit bats.

We already have a few volunteers who have started work in different parts of South Asia. South Asia is a large region and we need many more people.

Write to us at the earliest to be part of this long-term, first of its kind project:

\section{Ptero Count}

Sanjay Molur / Sally Walker / Sripathi Kandula (Scientific Chair), CCINSA

Zoo Outreach Organisation, 29-1 Bharathi Colony, Peelamedu, Coimbatore, Tamil Nadu 641004, India

Email: herpinvert@vsnl.com, zooreach@vsnl.com; Ph: +91 422 2568906, 2561743, 2561087; Fx: +91 4222563269 